\title{
PRZEKRACZANIE GRANIC W PROCESIE ZADOMOWIENIA
}

\section{The Crossing of the Borders in Process of the Settlemet}

Keywords: borders, settlement, space, house, anthropological place

Contact: Uniwersystet Ślaskiw Katowicach; adrianna.kus1@gmail.com

Perspektywa codziennego życia, w które wpisane są różnorakie granice, pozwala nam dostrzec, że nieustannie przekraczamy te granice zarówno fizycznie, jak i poprzez własne doświadczenia życiowe przeżywane wewnętrznie. Jednak szczególnym przypadkiem jest ten, kiedy przekraczamy granice, by wyznaczyć nowe, własne pogranicza, „oswoić” przestrzeń i wreszcie - zadomowić się w niej. Przestrzeń, w której żyje człowiek, postrzegana jako centrum świata o wyjątkowych właściwościach, wypełniona jest znaczeniami, dzięki którym możliwe staje się kategoryzowanie jej i dzielenie na poszczególne obszary (Tuan 1987: 189). Indywidualną kwestią jest decyzja o tym, które z miejsc włączymy w zakres przestrzeni zadomowionej, z którą nawiąże się szczególną relację. Nasuwają się więc pytania: jakiego rodzaju granice przebiegają przez najbliższe otoczenie człowieka i jego dom oraz jaką rolę odgrywają granice $\mathrm{w}$ procesie zadomowienia człowieka?

Zadomowienie to pojęcie nadal niedookreślone. Magdalena Łukasiuk w artykule $C z y(m)$ jest zadomowienie? (2018) wyznacza konteksty teoretyczne związane $\mathrm{z}$ wnętrzem domu i jego okolicą. Wśród perspektyw badań wymienia ciało jako punkt zerowy doświadczenia, kaufmannowskie wcielanie przestrzeni, perspektywę praktyk społecznych, bezdomność jako oderwanie praktyk zamieszkiwania od konkretnego miejsca, którym jest dom. Do rozważań tych włącza sąsiedztwo jako zewnętrzną perspektywę badawczą, ojczyznę prywatną i lokalność, a także mikropolis w ujęciu Andrzeja Nowaka. Wspólnym elementem tych wszystkich perspektyw jest przestrzeń, a konkretnie - specyficzna relacja człowieka z przestrzenią, którą tworzy przebywając w niej. Jak podaje Łukasiuk (2018: 11-12), wytwarza się między innymi przez cielesne obcowanie, poczucie przynależności i identyfikacji oraz praktyki. Relacja ta nie musi oznaczać przywiązania do domu rozumianego wyłącznie jako budynek, ale także do jego okolicy. Hanna Buczyńska-Garewicz postrzega tworzenie takiej relacji jako 
przebywanie w miejscu, które nabiera cech bliskiego zaznajomienia i zżycia z miejscem (Buczyńska-Garewicz 2006: 129). Dopiero gdy miejsce staje się własną okolicą rozumianą jako pewien obszar życia i jego otoczenie - nazywamy je domem. Ważnym czynnikiem wpływającym na zadomowienie jest zatem stosunek człowieka do konkretnej przestrzeni. Stosunek emocjonalny do miejsca zadomowionego odsyła także do kategorii miejsca antropologicznego. Są to historyczne punkty w przestrzeni, kreujące więzi społeczne, przyjmujące postać geometrycznego konstruktu zawierającego linie, przecięcia linii i punkty (Augé 2011: 37). Organizują przestrzeń oraz wyznaczają w niej granice, poza którymi ,inni ludzie definiowani są jako «inni»»"(Augé 2011: 37). Granice te wyczuwalne są intuicyjnie (na przykład najbliższa okolica granicząca $\mathrm{z}$ przestrzenią niezadomowioną), widoczne w przestrzeni (płoty wokół domu wyznaczające terytorium), ale też często konstruowane indywidualnie i niezbędne do określania własnej tożsamości (opozycja „my” - „oni”). Granica według Piotra Kowalskiego to „teren między przyległymi obszarami. Nie należąc do żadnego z nich, równocześnie je spaja i rozdziela" (Kowalski 1994: 150). W myśl tej definicji granica może być postrzegana jako peryferia danych obszarów, ale także początek jednego i drugiego. Zakłada zarówno podział, jak i włączenie dwóch różnych terytoriów w zakres większej całości. W przypadku zadomowienia, postrzeganie granic i peryferii danej przestrzeni zawsze odnoszone jest do konkretnego centrum, jakim jest własny dom. Jest to najbardziej prywatne miejsce zaspokajające różnorakie potrzeby ludzkie. Jak podaje Yi-Fu Tuan, ludzie mają skłonność do traktowania rodzinnych stron jako centrum świata (Tuan 1987: 189). Dom może być więc postrzegany jako axis mundi w indywidualnym doświadczeniu jednostki i jest miejscem sacrum (D. Benedyktowicz i Z. Benedyktowicz 1992: 27). W tym ujęciu jasno zarysowują się symboliczne granice sakralne, które oddzielają strefę chaosu od przestrzeni kosmicznej, uporządkowanej. Tymi symbolami przejścia są próg i drzwi w domu, zaś osiedlanie się w pewnym miejscu jest utożsamiane $\mathrm{z}$ położeniem podwalin świata (D. Benedyktowicz i Z. Benedyktowicz 1992: 26-28). Drzwi domowe pełnią rolę wejścia-tabu, które broni dostępu do drugiego świata (Gennep 2006: 44). Jest to więc znacząca, symboliczna granica, która mediuje między jednym światem a drugim. Broni dostępu do centrum świata jednostki, a wtargnięcie do wnętrza przez tę granicę stanowi złamanie tabu. Jest to także pierwsza, wyraźna, fizyczna granica, która dzieli przestrzeń na wnętrze i zewnętrze w procesie zadomowienia. Dopiero w dłuższym obcowaniu z miejscem, zżyciu z nim, tworzą się nowe granice pomiędzy tym, co zadomowione i niezadomowione. Wyznaczane są nowe punkty na mentalnej mapie danego miasta lub wsi. Przekraczanie granic pomiędzy tym, co znane i (jeszcze) nieznane pozwala nie tylko na poznanie konkretnego terenu, ale także na jego odczuwanie. Poruszanie się w przestrzeni i stopniowe przesuwanie granic daje możliwość zorientowania się w niej, 
wyodrębnia konkretnych miejsc oraz przeżycia tej przestrzeni. Jednostka dokonuje tego w codziennym doświadczeniu, w rutynowych, powtarzalnych czynnościach, jak na przykład codziennie pokonywanie trasy do pracy lub spacerowanie w celu poznania okolicy. Katarzyna Zarzycka za Yi-Fu Tuanem podaje, że „czucie” miejsca „wyłania się z doświadczeń, zwykle przelotnych i pozbawionych dramatyzmu, powtarzanych dzień po dniu i przez lata. Jest niepowtarzalną mieszanką widoków, dźwięków i zapachów, unikalną harmonią naturalnych i sztucznych rytmów, takich jak pora wschodu i zachodu czy pracy i zabawy. Czucie miejsca zarejestrowane jest w mięśniach i kościach" (cyt. za: Zarzycka, Tuan 2001: 183). Odczuwanie miejsca jest więc procesem wynikającym z powtarzalnych doświadczeń rejestrowanych przez ciało. „Czucie” miejsca zachodzi poprzez sensoryczne doznania i rytmiczne doświadczenia. W miarę poznawania nowej okolicy, możliwe staje się „odczuwanie” coraz większej liczby miejsc, które w pełni wykształca się dopiero po latach. W trakcie tego procesu człowiek rozgranicza miejsca zadomowione od miejsc niezadomowionych i obcych przestrzeni. Przykładem wyznaczania granic w obrębie okolicy własnego domu, a co za tym idzie - nawiązywania z nią relacji - są przydomowe ogródki zakładane wokół bloków w Nowej Hucie - dzielnicy Krakowa, opisane przez Ewę Baniowską-Kopacz w artykule „Nowohuckie podwórka” - od podwórka. Spojrzenie etnologa (2019). Według badaczki zakładanie ogródków na niewielkich, przydomowych obszarach było sposobem na wykreowanie własnego miejsca w nowym miejscu zamieszkania. Granice tego obcego świata były wyznaczane poprzez żywopłoty, ogrodzenia i furtki, uniemożliwiając dostęp do ogródków innym osobom. Baniowska-Kopacz (BaniowskaKopacz 2019: 72) podaje, że „potrzeba wydzielania w amorficznej przestrzeni obszarów znanych, bezpiecznych, swoich (Orbis Interior), od przestrzeni nieznanych, niebezpiecznych, obcych (Orbis Exterior) poprzez wyznaczanie granic i oddzielenie tych dwóch kategorii światów jest immamentną potrzebą człowieka”. Były to więc pierwsze próby zadomowienia obcych przestrzeni przez nowych mieszkańców osiedla. Przekroczenie granicy tego nieznanego terenu, które miało stać się domem, niosło za sobą potrzebę przesunięcia granic nieco dalej tak, aby okolica została zadomowiona. Takie działania pozwalały na stopniowe ,wczuwanie się” w miejsce poprzez rytm pracy w ogrodzie, doświadczanie miejsca i integrowanie się z nim.

Istotne jest także rozgraniczenie przestrzeni od miejsca. Yi-Fu Tuan podaje, że przestrzeń jest nieoswojona, pozbawiona znaczeń, wyczuwalnie rozległa, a także pozbawiona punktów odniesienia. Miejsce zaś jest konkretne, wyodrębnione z przestrzeni i zamieszkałe. Relację pomiędzy miejscem a przestrzenią charakteryzuje poniższy cytat: 
Przestrzeń stoi otworem; sugeruje przyszłość i zachęca do działania. (...) Jest jak pusta kartka, której znaczenie można dopiero nadać. Zamknięta i uczłowieczona przestrzeń staje się miejscem. W porównaniu $\mathrm{z}$ przestrzenią, miejsce jest spokojnym centrum ustalonych wartości. Istotom ludzkim potrzebne jest zarówno miejsce, jak i przestrzeń. Życie człowieka jest dialektycznym ruchem między bezpiecznym schronieniem a przygodą, przywiązaniem a wolnością (Tuan, 1987: 75).

Granica pomiędzy miejscem a przestrzenią jest wyraźnie zarysowana. Miejsce jest zarezerwowane dla człowieka, który zamieszkuje je i tworzy, a także odczytuje zawarte w nim znaczenia. Człowiek przekracza więc te granice nieustannie. Terytorium domu, wyodrębnione z przestrzeni, staje się zatem miejscem poprzez uczłowieczenie. Podobnie dzieje się w przypadku doświadczania obcej przestrzeni. W wyniku nadania jej osobistych znaczeń lub doświadczenia jej intymnie możliwe jest przekształcenie jej w miejsce. Intymne doświadczenie sprawia, że miejsce staje się w pewien szczególny sposób nacechowane pozytywnie, staje się wyjątkowe. Najdrobniejszy nawet gest, który zapada w pamięć, może stać się przyczynkiem do postrzegania miejsca jako intymnego. Tuan postrzega dom jako miejsce intymne ze względu na jego części i wyposażenie, odbierane również sensorycznie, które składają się na jego znaczenie (Tuan 1987: 183). Dom jest więc w pewnym sensie zbiorem miejsc znaczących, tworzących prywatną, spójną całość.

Inna definicja granicy zakłada podział przestrzeni na osobne, przyległe do siebie semiosfery. Jurij Łotman opisuje pojęcie granicy w następujący sposób:

Pojęcie granicy jest dwuznaczne. $Z$ jednej strony dzieli, z drugiej - łączy. Jest zawsze granicą z czymś i, co za tym idzie, należy równocześnie do obu pogranicznych kultur, obu przyległych do siebie semiosfer. (...) Jest to filtrująca membrana, która transformuje cudze teksty na tyle, żeby wpisywały się do wewnętrznej semiotyki semiosfery, pozostając jednakże obcymi (Łotman 2008: 213-214).

Granice są więc przede wszystkim łącznikiem obu obszarów, który przetwarza tekst jednej kultury i tłumaczy go na język drugiej kultury, chociaż nadal przynależy do tej pierwszej. Granica wydaje się mediować pomiędzy jednym obszarem a drugim. W takim ujęciu dom może być interpretowany jako najbliższa człowiekowi semiosfera, wypełniona konkretnymi znakami. Miejsca zadomowione wyodrębniają się z przestrzeni jako inne semiosfery zawierające odmienne, dobrze znane nośniki znaczeń. Pomiędzy obszarami niezadomowionymi a zadomowionymi przebiega wyraźna granica, która wydaje się najsilniej „transformować cudze teksty” tak, aby 
wpisywały się do ogólnej semiosfery danej okolicy. Fizyczne przekroczenie granic pomiędzy tymi miejscami sprawia, że człowiek, posługując się znanymi kodem, interpretuje i rozumie inne teksty.

Odmiennym przykładem przekraczania granic $\mathrm{w}$ procesie zadomowienia jest sytuacja przeprowadzki. Zmiana miejsca zamieszkania rozpatrywana będzie przeze mnie w kontekście próby zadomowienia na nowym terenie. Arnold van Gennep, opisując rytuały przejścia, wyróżnił trzy fazy: preliminalna, liminalna i postliminalnq. Pierwsza z nich odnosi się do wyłączenia jednostki z dawnego świata, druga związana jest ze stanem przejściowym, zaś ostatnia dotyczy włączenia do nowego świata (Gennep 2006: 45). Pierwszy etap przeprowadzki, rozpatrywany jako faza preliminalna, wiąże się często $\mathrm{z}$ odłączeniem jednostki od dotychczasowych domowników oraz z opuszczeniem miejsca, w którym mieszkała do tej pory. Przeprowadzkę poprzedzają przygotowania takie jak remont, zabezpieczenie własnych rzeczy przed przeniesieniem do nowego miejsca, czy zakup nowych przedmiotów i sprzętów. Mogą temu towarzyszyć pewne czynności związane z pożegnaniem z miejscem, czy z bliskimi. Druga faza - liminalna - następuje wtedy, gdy człowiek pozostaje zawieszony pomiędzy jednym miejscem a drugim. Nie należy już do dawnego porządku, nie wypracował nowego rytmu życia i nie nawiązał nowych relacji $\mathrm{z}$ ludźmi i „nieoswojonym” miejscem. W pewnym sensie nie należy już do dawnego świata i nie został jeszcze „włączony” do nowego. Zdarza się, że towarzyszy temu tęsknota za dawnym, zadomowionym miejscem, z które kiedyś stanowiło centrum życia jednostki. Ostatnia faza, postliminalna, to stan włączenia do społeczności, przyjęcia określonej roli społecznej $\mathrm{w}$ nowym środowisku, zaś relacja $\mathrm{z}$ miejscem jest wypracowana. Ta perspektywa pozwala zauważyć, że w tej fazie stan zadomowienia może, ale nie musi nastąpić. Przeprowadzka do nowego miejsca nie musi oznaczać zadomowienia się w nim. Poprzednie miejsce zamieszkania zmienia swój charakter z punktu widzenia osoby, która je opuściła. Zmianie ulega także relacja z dawnym domem.

Podsumowując, przekraczanie granic $\mathrm{w}$ rozpatrywanych przeze mnie kontekstach nie zawsze jest tożsame z zadomowieniem. Jednostka sama wyodrębnia z przestrzeni miejsca, z którymi nawiązuje szczególną relację między innymi poprzez intymne doświadczenia miejsca, „czucie” go, intuicyjne wyczuwanie pewnych granic przecinających przestrzeń, tworzenie własnych znaczeń w miejscu, a także przesuwanie granic tak, aby wyznaczyć swój teren. Jest to więc proces, na który składa się wiele czynników indywidualnych. Wyznaczanie granic swojego świata w opozycji do świata obcego jest jednak naturalną potrzebą człowieka, do której dąży posługując się konkretnymi praktykami. 


\section{Summary}

Borders are inseparable from space in which we live. Man is guided by the natural need to determine borders between what is 'his' and what is 'others'. His home and his settled area stand out from space as intimate places. Establishing a relationship with place allows to settle down in it. Long stay in the place and routine activities performed there allow to "feel" of place and its deeper understanding. The borders inscribed in the home space and the surrounding area are constantly crossed by man.

\section{Literatura}

Augé, M. Nie-miejsca. Wprowadzenie do antropologii hipernowoczesności. Warszawa: PWN, 2011.

Benedytkowicz, D. B. Dom w tradycji ludowej. Wrocław: Wiedza o Kulturze, 1992.

Buczyńska-Garewicz, H. Miejsca, strony, okolice. Przyczynek do fenomenologii przestrzeni. Kraków: UNIVERSITAS, 2006.

Gennep, A. Obrzędy przejścia. Warszawa: Państwowy Instytut Wydawniczy, 2006.

Baniowska-Kopacz, E. „Nowohuckie podwórka” - od podwórka. Spojrzenie etnologa. Journal of Urban Ethnology. 2019 (17).

Kowalski, P. Granica. Próba uporządkowania kategorii antropologicznych. In: Smolińska, T. (ed.) Pogranicze jako problem kultury. Opole: UO, 1994.

Lotman, J. Uniwersum umystu. Gdańsk: Wydawnictwo Uniwersytetu Gdańskiego, 2008.

Lukasiuk, M. Czy $(\mathrm{m})$ jest zadomowienie? In: Łukasiuk, M., Brosz, M. (eds.) Zadomowienie: konteksty empiryczne. Kawle Dolne: Wydawnictwo Zakładu Realizacji i Badań Społecznych Q\&Q, 2018.

Tuan, Yi-Fu Przestrzeń i miejsce. Warszawa: Państwowy Instytut Wydawniczy, 1987.

Zarzycka, K. Jak mieszka ,słoik”? Proces zadomawiania się w Warszawie na przykładzie studentów pochodzących spoza stolicy. Journal of Urban Ethnology. 2019 (17). 